\section{Life at and before the Institute of Archaeology:}

a personal retrospect David Harris

After a successful career in geography, David Harris became Professor of Human Environment at the Institute in 1980 and the Institute's Director in 1989 (Fig. 1). Here, David recalls his developing interest in archaeology and his years at the Institute, which saw significant improvements in facilities (notably the Wolfson Laboratories), the appointment of new staff and the encouragement of new directions in teaching and research.

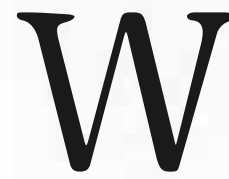

hen Ken Thomas kindly invited me to contribute to this issue of Archaeology International, my first thought was what a pleasure it would be just to write an article rather than edit the whole issue. Having retired from the job only last year, I well knew the magnitude of the task facing the new editor: one that is challenging and onerous but also intellectually rewarding. So I welcomed the opportunity to add my mite to the sequence of retrospective articles that have been a feature of $A I$ since it was launched nine years ago. But, unlike the former students and staff who have recalled in previous issues the early years in St John's Lodge in Regent's Park, my association with the Institute is much more recent. So rather than write only about the 1980s and 1990s, I have (with Ken's encouragement) taken a longer retrospective view, recalling how I followed a path from geography into archaeology, which led eventually to my joining the staff of the Institute in January 1980.

My earliest if rather tenuous link with the Institute goes back to 1947, when, as a schoolboy, I bought (for one shilling and sixpence) and read Pelican Book A108, What happened in history, by an author whose name meant nothing to me: Gordon Childe. ${ }^{1}$ In those early pre-television years after the war, when archaeology was an obscure minority pursuit, the idea that Europe, Egypt and Mesopotamia shared a prehistory that stretched back millennia before the civilizations of Greece and Rome was novel and exciting. I was already a geographer in the making, and Child's revelatory little book added a new dimension of deep time to my fascination with distant places. Later, reading geography at Oxford in the early 1950s, I seized the opportunity to take a subsidiary course in world ethnography, taught partly by the pioneer anthropologist Beatrice Blackwood (who had preceded Margaret Mead into the field in New Guinea). On Fridays, she used to take us to the Pitt-Rivers Museum, where she would unlock dusty cabinets and show us their wondrous contents. I remember one occasion when she whirled an Australian Aboriginal bullroarer round her head so fast that, tiny as she was, we expected her to rise in the air at any graduation I remained at Oxford to undertake research on arid land use in Tunisia for a BLitt degree. Seeing the dramatic Roman ruins there, and the traditional irrigation systems in the southern oases stimulated a growing interest in the ecology and early history of agriculture that was to become the principal theme of my research in later years.

In 1955 I was awarded a King George VI Memorial Fellowship to study in the USA and I chose to go to the University of California at Berkeley, although I knew little about what Berkeley might of fer to a young graduate student interested in the geography and history of arid lands. It turned out to be a serendipitous move that led ultimately to the Institute. At Berkeley I came under the influence of the scholarly and charismatic culturalgeographerCarl Sauer, whose influential - and controversial lectures to the American Geographical Society on worldwide agricultural origins and dispersals had recently been published. ${ }^{2}$ Becoming a teaching assistant and enrolling for a $\mathrm{PhD}$ at Berkeley allowed me to take specialized courses in botany and anthropology (including some archaeology), as well as to study with Sauer and his colleagues in the geography department. For my PhD I carried out an ecologicalhistorical study of land use in the Leeward Islands, ${ }^{3}$ and also wrote many course papers. Two papers, for Sauer's courses, I particularly remember: one on agriculture in prehistoric Europe, which introduced me to the seminal work of Grahame Clark, ${ }^{4}$ and the other on the distribution and ancestry of the domestic goat. The latter led several years later to my only meeting with Frederick Zeuner, at the Institute. Sauer had suggested that the goat paper was worth publishing, but I didn't act on his advice until the early 1960s, when, back in England in my first job in the University of London at Queen Mary College, I decided to send the paper to Zeuner for his opinion. He duly gave it: the first part sound, the second (in which I had discussed the symbolic significance of the scimitar-like horns of the wild bezoar goat as a possible factor in its domestication) much too speculative. In the event the first moment like a miniature helicopter. After

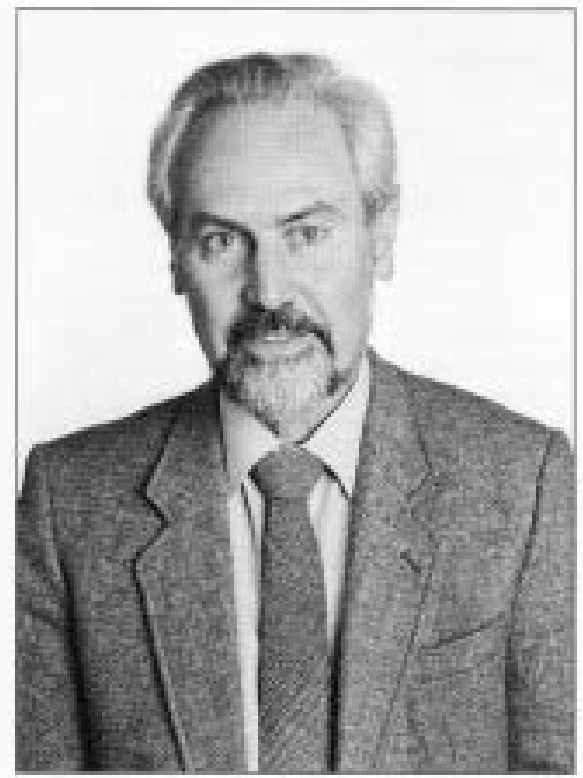

Figure 1 David Harris in 1989 when he was appointed Director of the Institute (photograph by Stuart Laidlaw).

part was published by the Linnaean Society, on Zeuner's recommendation. ${ }^{5}$

Otherenduring influences from my days at Berkeley in the late 1950s were Sauer's early papers on such grand themes in prehistory as the use and ecological effects of fire, and early human, especially coastal, migrations: prescient contributions, sadly now mostly forgotten, and to which I was recently able to draw renewed attention in a memorial lecture. ${ }^{6}$ At that time too was published the outcome of the world's first international symposium on man's role in changing the face of the Earth, which was held in Princeton, New Jersey, with Sauer as a prime mover. ${ }^{7}$ Known among the geography graduate students as the Berkeley Bible, it was a massive, extraordinarily wide-ranging volume that anticipated by many decades twenty-first-century concerns over conservation and the unbridled exploitation of the world's resources. When I moved to the Institute years later, I was pleased to find that my predecessor in the then Department of Human Environment, Geoffrey Dimbleby, recommended it to his students.

In London in the 1960s, first at Queen Mary College and from 1964 in the UCL Department of Geography, I became progressively more involved in aspects of teaching and research in the area where the interests of archaeologists, anthropologists and geographers overlapped. It was a time when a paradigm shift was taking place in the social sciences, one manifestation of which was the introduction of systems analysis and model building into geography and archaeology. The so-called "new geography" was led in Britain by Richard Chorley and Peter Haggett, while in the USA Lewis Binford and Kent Flannery pioneered the "new archaeology", followed later by David Clarke at Cambridge. ${ }^{8}$ 


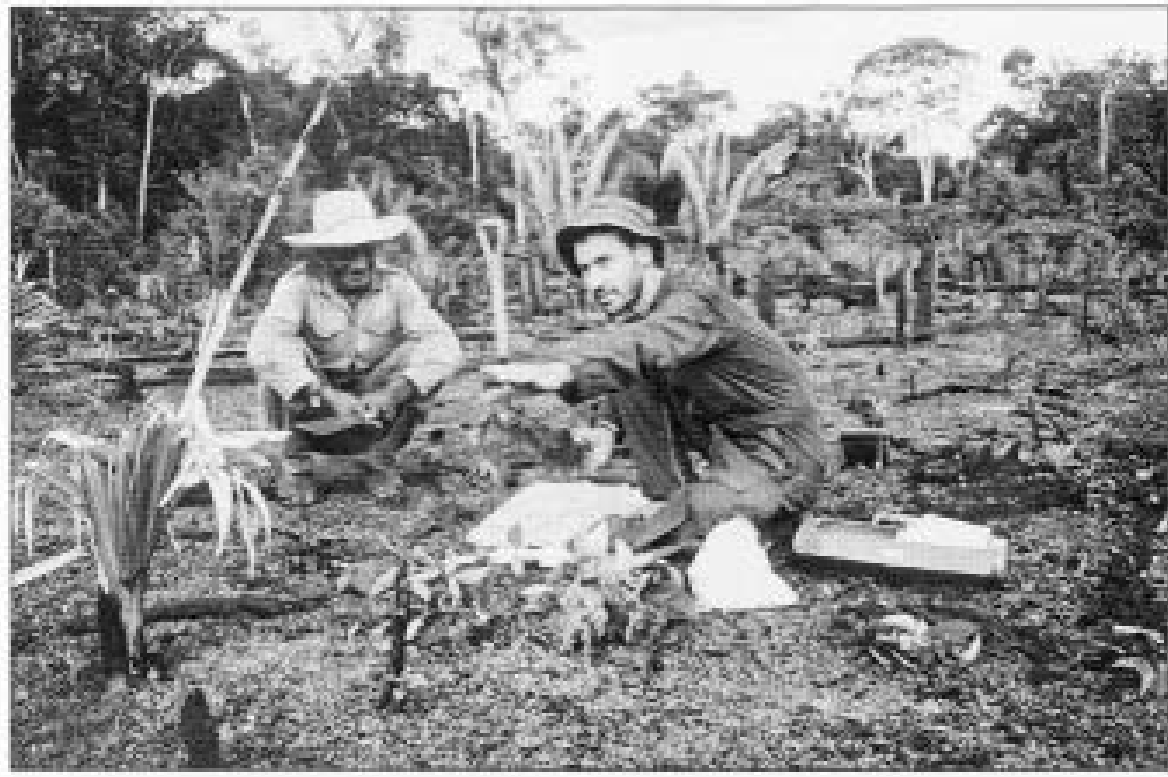

Figure 2 Fieldwork in a recently burned swidden clearing in the Venezuelan rainforest, on the upper Orinoco River near Esmeralda, April 1968.

This conceptual revolution was reflected in contributions to three international meetings of the Research Seminar in Archaeology and Related Subjects, which Peter Ucko founded when he was a young lecturer in the UCL Department of Anthropology. The first two, organized by Peter and Geoff Dimbleby, took place at the Institute in 1968 and 1970, and the third, organized by Colin Renfrew, was held at Sheffield in 1971. The three volumes to which they gave rise had an enduring influence on many areas of archaeological research, including plant and animal domestication and the origins and spread of agriculture. In my contributions to them I explored, in the first volume, an ecosystemic approach to the beginnings of plant cultivation and domestication, in the second the nature of swidden (shifting) cultivation and its relation to settlement, and in the third I proposed an ethnoecological model for the prehistory of tropical agriculture,

One of the participants in the first meeting in 1968 was Claudio Vita-Finzi, then a colleague in the Department of Geography (UCL), who famously invented, with Eric Higgs of the Cambridge archaeology department, the technique of site-catchment analysis. ${ }^{10}$ They were working together in an environmental-archaeological project at Palaeolithic sites near Ioannina in Epirus, and I joined their 1966 fieldwork season to study present-day vegetation in the area. Claudio and I also studied the spectacularly eroded badland topography of the Red Beds at Kokkinopilos in the Louros Valley south of Ioannina, which had been found to contain stratified Palaeolithic artefacts. ${ }^{11}$

It was during the 1960s too that I had an unexpected opportunity to return to the American tropics as a member of an ambitious expedition by hovercraft from
Manaus on the Amazon in Brazil to Port of Spain in Trinidad. It was a governmentinspired commercial venture aimed at demonstrating that a hovercraft could negotiate the $3200 \mathrm{~km}$ of rivers, rapids and sea from Manaus via the Rio Negro, the Casiquiare channel and the Orinoco to the Caribbean. I was one of three geographers invited to join the expedition to undertake hydrological, pedological and botanical studies along the route. The hovercraft was noisy and intrusive, and there were few chances for fieldwork as we followed the Negro upstream, so I then travelled for part of the way through the Casiquiare by dug-out canoe with a Venezuelan botanist, observing traditional shifting cultivation in the rainforest and collecting herbarium specimens (Fig. 2). We were able to visit a Yanamamo settlement on the Rio Ocamo, whose inhabitants combined cultivation of root crops and fruit trees with fishing and hunting. ${ }^{12}$ This experience made me realize that the sharp distinction conventionally made between hunter-gatherer and agricultural subsistence was a gross oversimplification, and that, at least in the tropics, systems that integrated smallscale cultivation with continuing exploitation of wild plants and animals were widespread.

This led me to think more generally about interactions between foragers and farmers elsewhere in the world, and in the 1970s I embarked on what became a major field project in the Torres Strait region between Australia and New Guinea. The strait had long been regarded as a boundary or frontier between hunter-gatherers and cultivators, and it seemed to be a promising locale for ethnographic, historical and archaeological study of past interaction between foragers and farmers. I began this new project in $1974,{ }^{13}$ and, after moving to the Institute in 1980, expanded it, with
Tony Barham and others, to include survey and small-scale excavation of coastal middens and relict field systems in the western islands of the strait and in coastal Papua New Guinea. ${ }^{14}$

In one sense, joining the Institute was just a matter of crossing Gordon Street and swapping a modest office in UCL's Foster Court building for the more spacious one overlooking Gordon Square on the third floor of the Institute, which had previously been occupied by GeoffDimbleby, but both academically and administratively it was a major change. It was a great pleasure to join environmental-archaeological and other Institute colleagues whose research interests were close to my own, and to have the chance through research grants and occasional staff appointments to build on the scientific foundations laid by Zeuner and developed by Dimbleby. When I arrived, the Institute's Department of Human Environment was already strong in zooarchaeology, with both Don Brothwell and Ken Thomas on the staff, but, with the exception of Joan Sheldon's work on archaeological wood charcoals, expertise in the archaeobotany of plant macro-remains was lacking. ${ }^{15}$ My first academic priority was to try to correct this imbalance.

Ialreadyknew that Gordon Hillman had carried out innovative archaeobotanical research in Turkey and had also retrieved a large assemblage of cereal and other charred plant remains from Epipalaeolithic and Neolithic levels at Tell Abu Hureyra in Syria during Andrew Moore's excavation of the site in the early 1970 s. $^{16}$ Abu Hureyra was a key site for investigating the beginnings of agriculture in Southwest Asia, and Gordon's job in the plantsciences department in Cardiff left him insufficient time to analyze the plant assemblagefully. So, with the agreement of his head of department, Alan Smith, I applied in 1981 to the SERC's ScienceBased Archaeology Committee for a threeyear research grant to enable Gordon to work full time on the project at the Institute. The application was successful, Gordon moved to the Institute and, as part of the project, he, Susan Colledge and I travelled extensively in Syria and Turkey in the spring of 1983, undertaking ecological surveys, collecting herbarium specimens and observing cultivation and cropprocessing practices. ${ }^{17}$ Being in the field with Gordon was a memorable educational experience, and one that I was fortunate to be able to repeat on later visits to Turkey and Turkmenistan in the early 1990s. A long-term position for him at the Institute was secured when he was appointed in 1983 to a lectureship in archaeobotany, which we had obtained through a University of London New Academic Initiatives competition, and the subject flourished under his inspiring leadership through the 1980s and 1990s. ${ }^{18}$

Another outcome of my close collaboration with Gordon was our joint editing of 


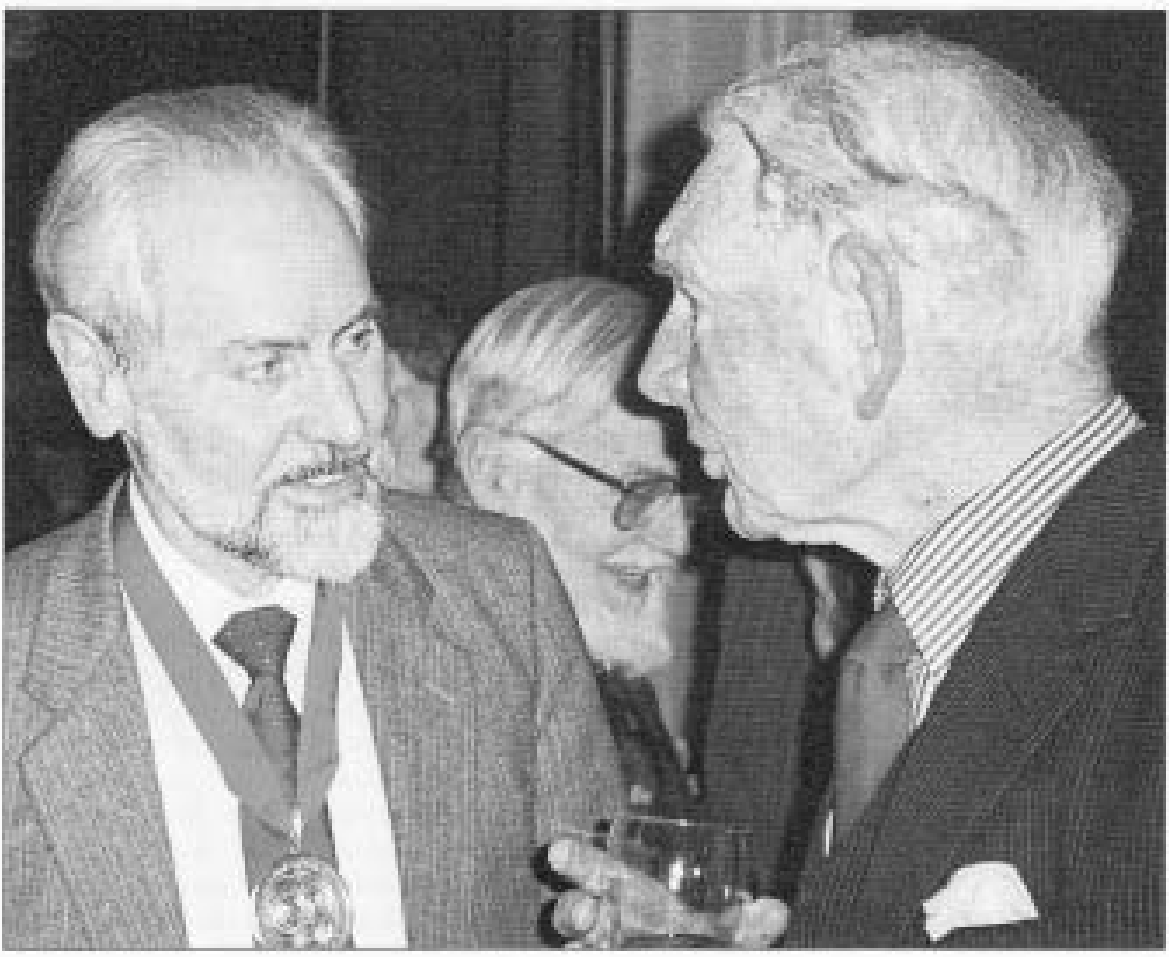

Figure 3 At a reception following the presidential address to the Prehistoric Society, with Professor Sir Grahame Clark (right) and Professor Thurstan Shaw (background centre), 16 February 1994 (photo by Zoë Harris).

a volume that had its origins in a symposium at the first World Archaeological Congress in Southampton in $1986 .{ }^{19}$ Our aim was to present ecological, ethnographic and archaeological evidence of agrarian and non- and pre-agrarian plant exploitation from many parts of the world in a comparativeevolutionary perspective. Some years later, in 1993, I organized an international conference at the Institute on a closely related theme, but this time I included animal as well as plant exploitation and restricted the geographical scope of the papers to Eurasia. Gordon and several other members of the Institute's staff contributed to the proceedings, which were published in $1996 .{ }^{20}$

Needless to say, my years as a full-time member of staff of the Institute, from 1980 to 1998 , were not devoted wholly or even mainly to research activities. Teaching, which I greatly enjoyed, was a major commitment at undergraduate and postgraduate levels. Among the courses that I recall with particular pleasure are a first-year introduction to human palaeoecology that I taught jointly with Ken Thomas, my own second- and third-year course "Resources and subsistence", which I gave every year, and a graduate seminar, "Plant domestications and dispersals", which was part of the MSc in bioarchaeology that we introduced in 1982/83. Administrative duties also took a great deal of my time, especially while I was director of the Institute from 1989 to 1996 , a period that included a major fund-raising effort to create laboratories and a secure artefact store in the basement, which culminated in 1991 with the opening of the Wolfson Archaeological Science Laboratories. ${ }^{21}$ Externally I was involved in many university committees and national organizations, notably the Science-Based Archaeology Committee (which I chaired from 1989 to 1992) and the Prehistoric Society, of which I was president of from 1990 to 1994 (Fig. 3). But throughout these busy years I was determined not to give up fieldwork entirely and in 1989 I began my last overseas project. It took place in the Karakum Desert in Turkmenistan and combined my enduring interest in the beginnings of agriculture with my early love of desert landscapes.

During the World Archaeology Congress in 1986 I met the famous Russian archaeologist Vadim Masson, who (following a visit to Russia by Peter Ucko and Tim Champion from the Department of Archaeology, University of Southampton) invited me to undertake, with British colleagues, environmental-archaeological work at the Neolithic site of Jeitun (Djeitun) on the southern edge of the Karakum (Fig. 4). Masson had excavated the upper levels of the site in the late 1950s and early 1960s, and it was regarded as the earliest known agricultural site in Central Asia. Gordon and I (and my wife Helen) made a preliminary visit to the site in 1989 and it was soon apparent that its deposits contained abundant charred plant remains (Fig. 5). We returned in 1990 with a larger team and participated in renewed excavations with Russian and Turkmen colleagues. Our initial aim was to retrieve and date cereal grains by the accelerator mass-spectrometric radiocarbon method to test whether
Masson, who had not obtained any radiocarbon dates from the site, had been right to infer that Jeitun was occupied in the sixth millennium BC. We obtained dates from grains and chaff of domestic einkorn wheat, which, together with bones of wild animals and domestic goats and sheep, confirmed that the site was occupied by c. $6000 \mathrm{BC}$ (calibrated) and that its Neolithic inhabitants were agropastoralists who also hunted gazelle and other wild herbivores. ${ }^{22}$ The project was expanded through the 1990s to include further excavations and ecological and geoarchaeological fieldwork at Jeitun and elsewhere in southern and western Turkmenistan, and our final field season took place in $1997 .^{23}$

Looking back over my long association with the Institute, first as a near neighbour in the UCL Department of Geography and later as a member of staff, I rejoice in its vision of an archaeology that is not narrowly specialized but encompasses almost all humanistic and scientific aspects of the subject, welcomes collaboration with related disciplines, and, above all, regards the whole world as within its remit - a vision that accords closely with my own studies, in diverse parts of the world, of past human subsistence and the origins and spread of agriculture. ${ }^{24}$

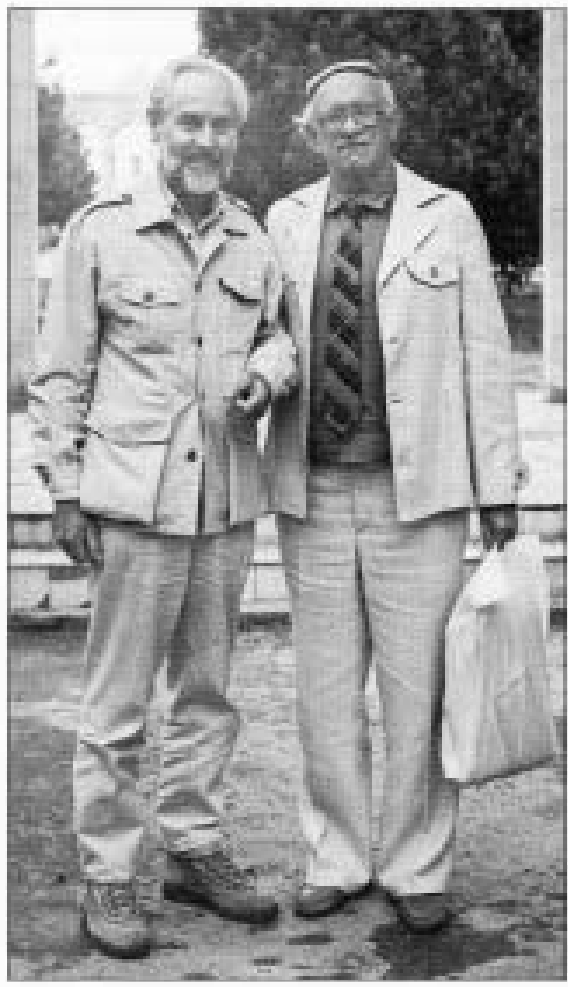

Figure 4 With Professor Vadim Masson at the entrance to the Inst itute of History of the Turkmen Academy of Sciences, Ashgabat, April 1992. 


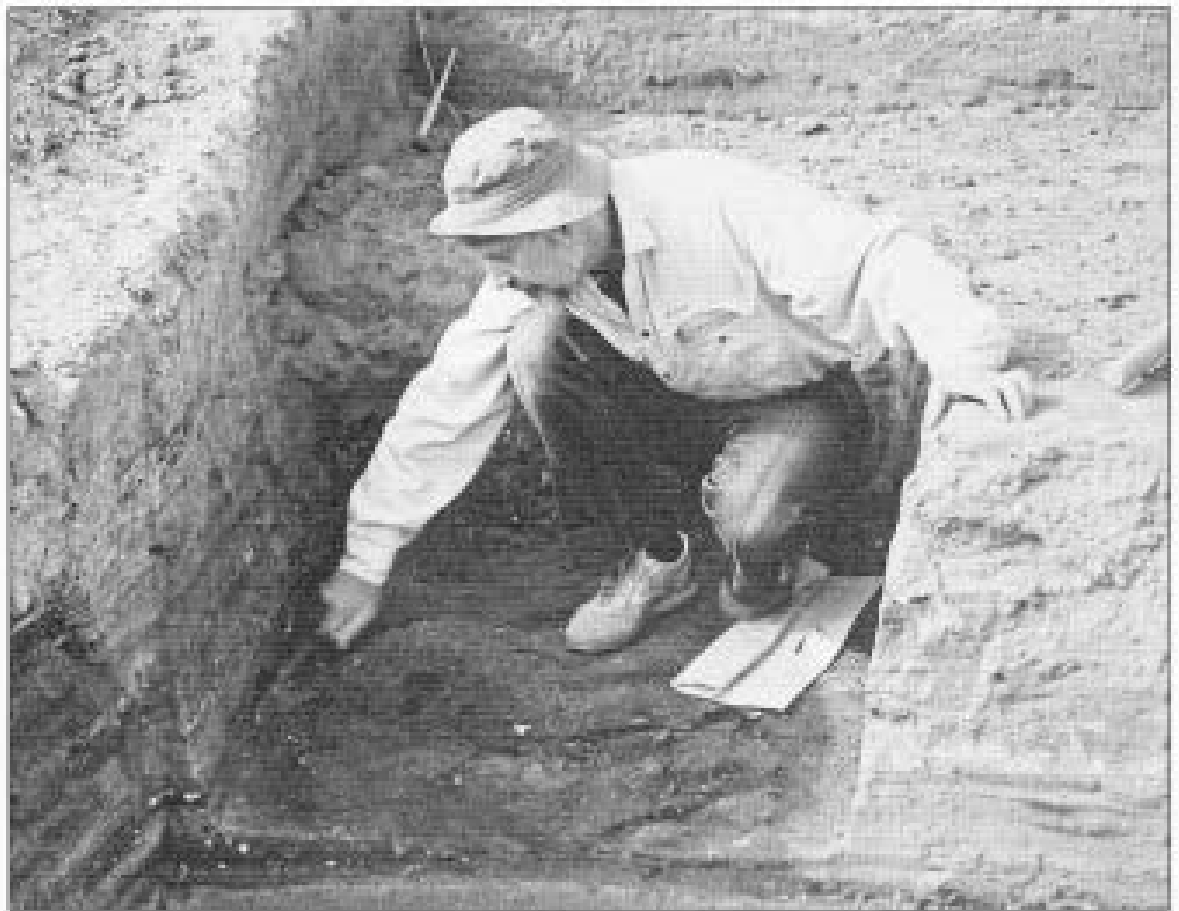

Figure 5 Excavating charred hearth deposits at Jeitun, Turkmenistan, April 1993.

\section{Notes}

1. How incredulous I would have been had I known then that one day I would organize a conference at the Institute to celebrate the centennial of Childe's birth; see The archaeology of $V$. Gordon Childe: contemporary perspectives, D. R. Harris (ed.) (London: UCL Press, 1994).

2. Agricultural origins and dispersals, C. O. Sauer (New York: American Geographical Society, 1952).

3. Plants, animals and man in the outer Leeward Islands, West Indies: an ecological study of Antigua, Barbuda and Anguilla, D. R. Harris (Berkeley: University of California Press, 1965).

4. Prehistoric Europe: the economic basis, J. G. D. Clark, (London: Methuen, 1952).

5. D. R. Harris, "The distribution and ancestry of the domestic goat", Proceedings of the Linnean Society of London 196061(2), 79-91, April 1962.

6. D. R. Harris, " "The farther reaches of human time': retrospect on Carl Sauer as prehistorian”, Geographical Review 92, 526-44, 2002.

7. Man's role in changing the face of the Earth, W. L. Thomas Jr (ed.) (Chicago: University of Chicago Press, 1956).

8. See Models in geography, R. J. Chorley \& P. Haggett (eds) (London: Methuen, 1967); L. R. Binford, "Post-Pleistocene adaptations" in New perspectives in archeology, S. R. Binford \& L. R. Binford (eds), 313-41 (Chicago: Aldine, 1968); K. V. Flannery, "Archeological systems theory and early Mesoamerica" in Anthropological arche ology in the Americas, B. J. Meggers (ed.), 67-87 (Washington DC: Anthropological Society of Washington, 1968); and Models in archaeology, D. L. Clarke (London: Methuen, 1972).

9. Harris, D. R., "Agricultural systems, ecosystems and the origins of agriculture", in The domestication and exploitation of plants and animals, P. J. Ucko \& G. W.
Dimbleby (eds), 3-15 (London: Duckworth, 1969); "Swidden systems and settlement", in Man, settlement and urbanism, P. J. Ucko, R. Tringham, G. W Dimbleby (eds), 245-62 (London: Duckworth, 1972); and "The prehistory of tropical agriculture: an ethnoecological model", in The explanation of culture change: models in prehistory, C. Renfrew (ed.), 391-417 (London: Duckworth, 1973).

10. C. Vita-Finzi \& E. S. Higgs, "Prehistoric economy in the Mount Carmel area of Palestine: site catchment analysis", Proceedings of the Prehistoric Society $\mathbf{3 6}$ 1-37, 1970.

11. E. S. Higgs, A. E. Fagg, C. Vita-Finzi, D. R Harris, "The climate, environment and industries of Stone Age Greece: part III", Proceedings of the Prehistoric Societ y $\mathbf{3 3}$ 1-29, 1967; and D. R. Harris \& C. VitaFinzi, "Kokkinopilos - a Greek badland", Geographical Journal 134, 537-46, 1968.

12. See D. R. Harris, "The ecology of swidden cultivation in the upper Orinoco rain forest, Venezuela", Geographical Review 61, 475-95, 1971 .

13. See D. R. Harris, "Subsistence strategies across Torres Strait”, in Sunda and Sahul: prehistoric studies in Southeast Asia. Melanesia and Australia, J. Allen,

J. Golson, R. Jones (eds), 421-63 (London: Academic Press, 1977).

14. See A. J. Barham \& D. R. Harris, "Prehistory and palaeoecology of Torres Strait" in Quaternary coastlines and marine archaeology: towards the prehistory of land bridges and continental shelves, P. M. Masters \& N. C. Flemming (eds), 549-57 (London: Academic Press, 1983) and "Relict field systems in the Torres Strait region" in Prehistoric intensive agriculture in the tropics, I. S. Farrington (ed.), 247-83 (Oxford: British Archaeological Reports, International Series 232 (i), 1985).

15. Geoffrey Dimbleby's archaeobotanical expertise was in pollen analysis rather then the study of plant macro-remains. He pioneered the technique of archaeological soil-pollen analysis, summed up after his retirement in his book The palynology of archaeological sites (London: Academic Press, 1985), and he recalled his years at the Institutein Archaeology International 1998/1999, pp. 9-10.

16. See G. C. Hillman, "Crop husbandry and food production: modern models for the interpretation of plant remains", Anatolian Studies 23, 241-44, 1973; and "The plant remains from Tell Abu Hureyra: a preliminary report", within "The excavation of Tell Abu Hureyra in Syria: a preliminary report”, A. M. T. Moore, 70-73, Proceedings of the Prehistoric Society 41, 50-77, 1975.

17. One particularly memorable incident occurred during our field work in 1983 in a remote part of northeastern Turkey. We were searching for emmer wheat said still to be under cultivation in the area when our Land Rover was ambushed by three young soldiers who marched us at rifle point across country to a small command post, from where we were driven to a nearby town, incarcerated overnight, and released the following day only when intervention from Ankara convinced the military authorities that we were not Armenian terrorists.

18. For an account of those years, and of the beginnings of environmental archaeology at the Institute, see D. R. Harris, "Gordon Hillman and the development of archaeobotany at and beyond the London Institute of Archaeology" in Ethnobotanist of distant pasts: papers in honour of Gordon Hillman, A. Fairbairn \& E. Weiss (eds) (Oxford: Oxbow Books, 2007).

19. Foraging and farming: the evolution of plant exploitation, D. R. Harris \& G. C. Hillman (eds) (London: Unwin Hyman, 1989).

20. The origins and spread of agriculture and pastoralism in Eurasia, D. R. Harris (ed.) (London: UCL Press, 1996).

21. For details of theinitial design of the Wolfson Laboratories, and a brief account of the history of the Institute, see D. R. Harris, "Sixty years on: the Institute of Archaeology, 1937-97”, ArchaeologyInternational 1997/1998, 3-5. In 2004-2005 the laboratories underwent a major refurbishment and much of the instrumentation was upgraded (see p. 5).

22. See D. R. Harris, V. M. Masson, Y. E. Berezkin, M. P. Charles, C. Gosden, G. C. Hill man, A. K. Kasparov, G. F. Korobkova, K. Kurbansakhatov, A. J. Legge, S. Limbrey, "Investigating early agriculture in Central Asia: new research at Jeitun. Turkmenistan", Antiquity 67, 324-38, 1993.

23. A volume reporting the results of this project is in preparation: Origins of agriculture in western Central Asia: archaeological and environmental investigations in Turkmenistan.

24. As expressed in my contribution to the recently published festschrift for Peter Ucko: "The multidisciplinary study of agricultural origins: 'One World Archaeology' in practice?", in A future for archaeology: the past in the present, R. Layton, S. Shennan, P. Stone (eds), 229-44 (London: UCL Press, 2006). 